\title{
Implications of Extracellular Polymeric Substance Matrices of Microbial Habitats Associated with Coastal Aquaculture Systems
}

\author{
Juan Carlos Camacho-Chab ${ }^{1, \dagger}{ }^{\dagger}$ Fabiola Lango-Reynoso ${ }^{1, \dagger}{ }^{\dagger}$, María del Refugio Castañeda-Chávez ${ }^{1, \dagger}$, \\ Itzel Galaviz-Villa ${ }^{1,+}$, Demian Hinojosa-Garro ${ }^{2,+}$ and Benjamín Otto Ortega-Morales ${ }^{3, *}$ \\ 1 Laboratorio de Investigación en Recursos Acuáticos LIRA, Instituto Tecnológico de Boca del Río, \\ Kilómetro 12, Carretera Veracruz-Córdoba, Boca del Río 94290, Veracruz, Mexico; \\ juanccam@uacam.mx (J.C.C.-C.); fabiolalango@yahoo.com.mx (F.L.-R.); \\ castanedaitboca@yahoo.com.mx (M.d.R.C.-C.); itzelgalaviz.itboca@gmail.com (I.G.-V.) \\ 2 Laboratorio de Vida Silvestre, Área de Ecología Acuática, CEDESU, Universidad Autónoma de Campeche, \\ Colonia Buenavista, San Francisco de Campeche 24039, Campeche, Mexico; dhinojos@uacam.mx \\ 3 Centro de Microbiología Ambiental y Biotecnología DEMAB, Universidad Autónoma de \\ Campeche Colonia Buenavista, San Francisco de Campeche 24039, Campeche, Mexico \\ * Correspondence: beortega@uacam.mx; Tel.: +52-981-811-9800 (ext. 207-0101) \\ $\dagger$ These authors contributed equally to this work.
}

Academic Editor: Kevin B. Strychar

Received: 11 March 2016; Accepted: 19 August 2016; Published: 27 August 2016

\begin{abstract}
Coastal zones support fisheries that provide food for humans and feed for animals. The decline of fisheries worldwide has fostered the development of aquaculture. Recent research has shown that extracellular polymeric substances (EPS) synthesized by microorganisms contribute to sustainable aquaculture production, providing feed to the cultured species, removing waste and contributing to the hygiene of closed systems. As ubiquitous components of coastal microbial habitats at the air-seawater and seawater-sediment interfaces as well as of biofilms and microbial aggregates, EPS mediate deleterious processes that affect the performance and productivity of aquaculture facilities, including biofouling of marine cages, bioaccumulation and transport of pollutants. These biomolecules may also contribute to the persistence of harmful algal blooms (HABs) and their impact on cultured species. EPS may also exert a positive influence on aquaculture activity by enhancing the settling of aquaculturally valuable larvae and treating wastes in bioflocculation processes. EPS display properties that may have biotechnological applications in the aquaculture industry as antiviral agents and immunostimulants and as a novel source of antifouling bioproducts.
\end{abstract}

Keywords: extracellular polymeric substances; microbial habitats; coastal aquaculture; marine biotechnology

\section{Introduction}

Coastal regions are comprised of the continental shelf (to a depth of $200 \mathrm{~m}$ ), the intertidal zone and adjacent land within $100 \mathrm{~km}$ of the coastline [1]. Coasts include rocky shores, sandy beaches, mudflats, saltmarshes, mangrove forests, deltas and coral reefs [2]. These regions provide goods and services including recognizable mineral and oil resources, construction materials, human and animal food, recreation and living sites, energy sources and biotechnological products, among others [1,3], along with less tangible benefits including ecosystem services such as erosion and flood control, carbon sequestration and wildlife habitat [4]. Production of food for human populations derived from fishing activity is one of the most important services provided by coastal zones. The decline of fisheries worldwide has fostered the development of marine aquaculture [5], an economic activity 
that accounts for approximately $40 \%$ of the world aquaculture production; it reached a production of 24 million tonnes in 2012 [6]. If the definition of coasts given above is taken into consideration, marine aquaculture activities according to Lucas [7] might include extensive and intensive freshwater aquaculture production, if the production facilities are located within $100 \mathrm{~km}$ of the coastline. However, using a more restricted definition and for the purpose of this review, marine aquaculture will refer to culturing activities of marine species in shore-based installations (i.e., marine fishes), marine cage aquaculture and shellfish farming. This emphasis is justified since shellfish and finfish productions represent $25 \%$ of global animal marine aquaculture, $75 \%$ being for shellfish production (e.g., mussel, oyster, lobster) and the remainder for finfish such as salmon and bream [6], because both open-ocean and deep-sea aquaculture are still nascent fields.

On the other hand, microorganisms occupy major coastal habitats, thriving either as planktonic communities in the water column, as benthic assemblages on hard and soft bottoms, or as epi/endobiotic components when associated with living plants and animals [8,9]. Microorganisms contribute to sustainable aquaculture practices primarily by serving as food sources and maintaining water quality by recycling the excess nutrients derived from faeces, dead organisms and unconsumed food [10]. It is well established that microorganisms occur as biofilms in natural ecosystems; these biofilms are complex microbial communities attached to surfaces and held together within a matrix of self-produced extracellular polymeric substances (EPS) or exopolymers [11,12]. EPS may also be associated with microbial communities present on interfaces such as neuston (air-seawater), microphytobenthos (seawater-sediment) or cellular aggregates, such as bioflocs, as well as be part of transparent exopolymeric particles (TEP) [13-16]. TEPs have already been extensively studied in aquatic ecosystems $[17,18]$, thus they will be only be discussed here in the context of coastal aquaculture. It is often stated that EPS represent up to $90 \%$ of the total organic matter comprising biofilm or microbial aggregate biomass [12]; EPS are also excreted into the surrounding medium, contributing to the pool of dissolved organic matter (DOM) or as precursors of TEP [18,19]. EPS play a key role in primary productivity, trophic linkage and mobilization of pollutants mediated by marine microbial communities [3,11].

It has recently been recognized that microbial EPS may contribute to aquaculture in a number of ways. In a recent review, Joyce and Utting [20] described the roles played by EPS in hatcheries by attracting commensal bacteria and sequestering nutrients, which contribute to hygiene, stabilization of larval rearing systems, production of microalgal feed and in the development of the larval gut microflora. This review is restricted to describing the influences of EPS in coastal aquaculture systems. First, we provide a view of the ubiquity of microbial habitats, highlighting their biofilm/microbial aggregate lifestyle and the relevance of constitutive EPS that mediate processes relevant to coastal aquaculture settings. We have limited our analysis to studies describing actual or potential impact of EPS on aquaculture systems in marine cage aquaculture, shellfish farming and in shore-based systems cultivating marine species, as they represent most of the current activity in marine aquaculture. We felt it appropriate also to emphasize EPS properties that may have future biotechnological implications for the aquaculture industry.

\section{Biofilm and Aggregates Dominate Microbial Habitats in Coastal Zones}

It has been well documented that most microbes occur as biofilm communities, which have been the dominant microbial life form on Earth [21]. The term 'biofilm' was coined and first described by Costerton et al. [22] and has evolved ever since. Microorganisms can develop as biofilms on a number of different surfaces in aquatic and terrestrial environments, as well as on living tissues, medical devices and industrial systems [23,24]. Biofilms and sessile biofilm-like structures (for instance, neuston and microbial mats), although commonly associated with solid-surfaces, may occur on any type of interface including air-liquid, liquid-liquid, solid-liquid, or air-solid interfaces [25]. There are numerous features that distinguish microbial cells in biofilms from those in planktonic (free-living) communities. These include, high population densities, access to nutrients in both nutrient-poor and nutrient-rich situations 
and especially the presence of an EPS matrix [26]. EPS confer on biofilms mechanical stability, binding of water, sorption of organic and inorganic molecules, enhanced resistance towards antimicrobials and may act as a diffusion barrier, creating a microenvironment surrounding cells for optimal extracellular enzyme activity [12].

Substrata such as rocks, sediment beds, plants and animal tissues, along with any submerged artificial surface (nets, piers, buoys, floating platforms and ship hulls) are available for microbial colonization in marine ecosystems. For the purpose of this review, we consider the floating microbial communities occurring at the air-water interface (bioflocs and microneuston) along with microbial mats and microphytobenthic communities (water-solid interfaces) analogous to true biofilms (i.e., biofilm-like). These inclusions are based on key structural and functional traits displayed by biofilms, including high cell density, microcolonial aggregation and occurrence of exopolymeric matrices that embed cells.

Neuston biofilms dwell on the air-water interface of the atmosphere and the surface of the water column. The concentration of hydrophobic and surface-active substances (materials that can greatly reduce the surface tension of water, i.e., surfactants or biosurfactants) and bacterial cells within neuston communities may be three orders of magnitude higher than in bulk water [27]. Biodiversity of microbial neuston includes the distribution of bacterial species, generic variants of one species, and cells within the different phases of cell cycles or different stages of the life cycle [13]. Due to this diversity of species and different trophic levels that coexist in this habitat, the microneuston is a particular microbial community $[13,28]$. Microbial neuston and its associated EPS contribute substantially to the formation of the sea-surface microlayer (SML), a boundary between the atmosphere and seawater surface [29]. The SML is a hydrated gelatinous layer of polymeric nature, in which the polysaccharide fraction dominates. The presence of SML may have important, not yet recognized, implications for coastal aquaculture, by retarding oxygen exchange and thereby negatively impacting cultured marine animal species (finfish), or also, given their surfactant nature and chemistry, trapping airborne hydrophobic pollutants and metals, and transferring them to the water column and ultimately to the sediment phase, where cultured finfish and particle-feeding invertebrates can potentially ingest them.

On the other hand, the biofilms occurring at the water-solid interfaces are more conspicuous. These can be classified as epibiotic biofilms, when developing associated with the outer body surface (tissues of living organisms) or simply as biofilms when they grow on inanimate surfaces. Epibiotic biofilms are in turn classified as epiphytic biofilms (also often termed periphyton [30]), when they develop mainly on submerged plants (leaves, blades, stipe, holdfast) and, in principle, also those microbial populations surrounding phytoplankton (phycosphere) [14]. Epiphytic biofilms are comprised of algae, fungi, bacteria and protozoa, in which the phototrophic component (prokaryotic and eukaryotic) usually dominates [15]. These populations play a major role in primary productivity and thus provide a food source for fish, crustaceans and mollusks [31], transferring carbon along the food web in both freshwater and coastal marine ecosystems [32,33]. Also, when microbial biofilms colonize branches of decayed wood from mangrove swamps and other coastal woody tree species, the term epixylic communities applies [34]. The consequences of epiphytic biofilm development include both deleterious and positive effects on the host [35]. The same applies for microbial-animal interactions in the form of epizootic biofilms that live in intimate association with the bodies and tissues of marine organisms. The composition and density of epizootic bacterial communities associated with marine organisms greatly varies both at temporal and spatial scales within individuals, among species, habitats, regions, and seasons [30].

According to Martinez et al. [1], rocky shores are important geomorphological features of the world's coastal zones. Hard bottoms are readily colonized by epilithic (rock-surface) biofilms comprising algae, bacteria and fungi, and associated microfauna. Other hard substrata such as concrete supports of piers and bridges are also colonized by this type of biofilm. Interesting to note is that estuaries in Australia, the United States and Europe have had more than $50 \%$ of their natural coastline modified with artificial structures [36]. Therefore, concrete and other building materials represent a 
significant novel microbial habitat in the coastal zone. Epilithic microalgae and cyanobacteria generally account for more than $30 \%$ of the total biofilm biomass, and such phototrophs influence both the biomass and diversity of non-photosynthetic bacteria [37]. These biofilm communities are important for primary production and biogeochemical cycling of carbon and nutrients along tropical intertidal rocky shores [38]. On the other hand, microbial flocs, defined as aggregated suspended sediments composed of microorganisms (bacteria and algae), are structured by a tangled EPS network that traps particles, colloids, cations and dead cells [39]. Settling microbial flocs may form a dynamic interface between the water column and the sediments, significantly impacting biogeochemical cycling in shallow waters, driving fixed carbon from highly productive suspended flocs to the sediments, influencing benthic metabolism [40]. Microphytobenthic biofilms are communities found in the upper millimeters of the sedimentary phase and are involved in stabilizing the particles from flocs. In highly turbid intertidal areas, microphytobenthic biofilms contribute up to $50 \%$ of primary production, representing a significant food source for cultivated oysters [41]. The fact that sandy shores are found on $16 \%$ of the coastal countries and given the high share of carbon fixation contributed by microphytobenthic biofilms, it is likely that these microbial communities have a major role at the planet level, mediating the flux of nutrients between sediment and the water column, a process where EPS may have a substantial relevance [42].

Marine biofilms also grow associated with immersed artificial substrata including those comprised of metals, polymers and composites $[43,44]$. The formation of biofilms on a newly submerged substrate facilitates the subsequent colonization of macroorganisms such as invertebrate larvae and algal spores [45]. Biofilms can mediate not only the level of colonization but also the type of macrofoulers. Microbial biofilms provide chemical cues for specific colonizers; these microbial cues interplay with chemical cues from conspecific individuals that contribute to the colonization process [46,47]. There is an international consensus on the highly deleterious influence of biofouling on marine infrastructure and the shipping industry around the world [48], by reducing the flow of water through the net, affecting oxygen supply and the waste removal, which in turn increase the susceptibility of farmed fish to diseases [49]. Figure 1 depicts a marine coastal ecosystem with integrated aquaculture systems, focusing on the most relevant microbial habitats.

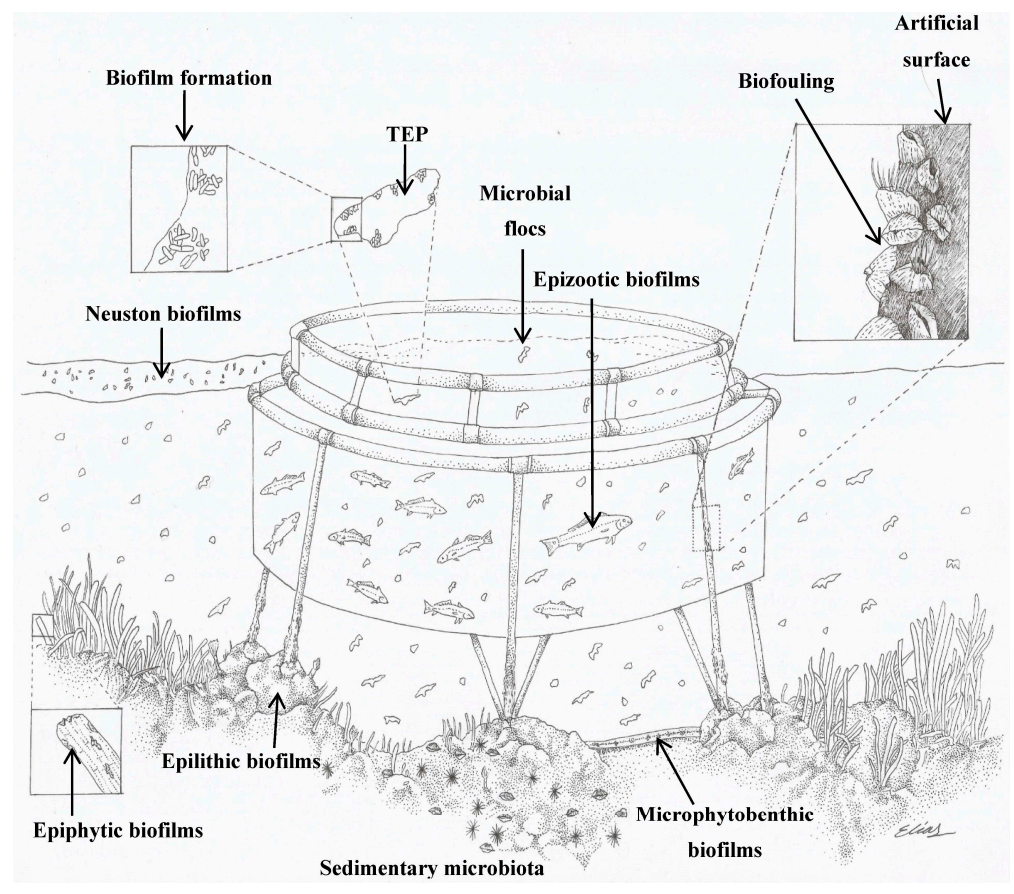

Figure 1. Diagram of a marine coastal aquaculture system depicting major microbial biofilm habitats as discussed in references [27-45]. TEP: Transparent exopolymer particles. 


\section{Extracellular Polymeric Substances (EPS) as Key Components of Biofilms and Microbial Aggregates}

The EPS matrix accounts for more than $90 \%$ of the mass of biofilms on a dry weight basis [12]. EPS exist at different cellular levels and can thus be divided into bound EPS (sheaths, capsular polymers, transparent condensed gels, loosely bound polymers, and attached organic materials) and soluble EPS (soluble macromolecules, colloids, and slimes) [50]. Bound EPS as their name implies are closely bound with external surfaces of cells, while soluble EPS are weakly bound to cells or dissolved into the surrounding solution [51]. The chemistry of EPS varies and may thus include high molecular weight organic molecules such as polysaccharides, proteins, nucleic acids, lipids and a lesser proportion of other low molecular weight nonpolymeric constituents [52]. Some EPS are neutral macromolecules, but most are polyanionic and contain abundant functional groups, such as carboxyl, phosphoric, amine and hydroxyl groups. These functional groups are negatively charged and play a role in metal adsorption by electrostatic attractions [53]. However, the composition and quantity of the EPS vary depending on the type of microorganisms, age of the biofilms and the different environmental conditions under which the biofilms exist [52].

EPS serve several ecological functions in biofilms. These include, but are not restricted to, aggregation of bacterial cells (bioflocs) and provision of physical means of adherence to surfaces (biofilms). They also serve as immediate microenvironments to optimize extracellular enzymatic activity, sorption of nutrients, and enhanced exchange of genetic information and resistance towards antimicrobials. They also provide a protective barrier and a reservoir of water which is important under desiccation stress, in particular for intertidal biofilms [12,21]. A major pool of EPS in marine environments is represented by transparent exopolymer particles (TEP), which are transparent microgels, abundant $\left(10^{3}\right.$ to $\left.10^{6} \mathrm{~mL}^{-1}\right)$ in both open oceans and coastal waters with size ranging from $<1 \mu \mathrm{m}$ to $200 \mu \mathrm{m}[17,18]$. TEP occur extensively in the marine environment and have several origins. They may derive directly from EPS of phytoplankton and bacteria, arising from degradation processes of marine snow and other detrital material, or may even be formed abiotically from organic precursors $[17,54]$. Independently of the origin, TEP exhibit in general surface-active behavior and represent the main vehicle for fast downward flux of organic matter and sedimentation of particulate matter in oceans [54]. TEP are likely of high relevance in coastal areas where aquaculture is developed, given the close coupling of planktonic and benthic process typical of shallow waters. Surprisingly, there is scant information on the occurrence of TEP in aquacultural settings, despite the fact that they can be considered as a significant fraction of the bioflocs in inshore facilities or in marine cages. In addition, EPS derived from TEP may play an active role in coating submerged surfaces, forming primary films that lead to intense microbial colonization [11]. Despite the process described above, the relevance of EPS in aquaculture has just recently caught the attention of researchers. In a seminal review, Joyce and Utting [20] summarized EPS implications in closed, controlled aquaculture systems (hatcheries). These authors highlighted the impact of EPS in microalgal feed production and larval rearing systems. These processes are highly relevant to inland culturing of marine species in closed recirculating systems, but may have limited implications in coastal open aquaculture. These implications are discussed below.

\section{Microbial EPS Interacting with Coastal Aquaculture Systems: Practical Implications}

\subsection{Control of Biofouling}

The colonization of immersed surfaces by micro and macroorganisms is a complex sequential process. Upon immersion, surfaces are conditioned by adsorbed organics, such as polysaccharides and proteins. Conditioned surfaces are then colonized by bacteria (first settlers), diatoms, and other microorganisms bound together in a matrix of EPS (biofilm) [24,55,56]. EPS are responsible in the adhesion of bacteria to the surfaces [57]. The ability of bacteria to perform this initial attachment is controlled by both environmental and genetic factors, such as nutrient levels, temperature, $\mathrm{pH}$ and the presence of genes encoding motility functions [58,59]. Over time, as biofilms grow and reach 
mature stages, they increase in cell density and structural complexity [51]. Subsequent microbial interactions may lead to attachment and growth of invertebrates (i.e., barnacles, tunicates, mussels, bryozoans, polychaetes, tubeworms) and macroalgae (i.e., Enteromorpha intestinalis, Ulothrix zonata) over a period of days or weeks $[30,60]$. When biofilms lead to the settlement of macroorganisms on artificial immersed surfaces, the phenomenon is named biofouling [30].

Marine biofouling is a worldwide problem affecting artificial substrates such as nets, piers, buoys, floating platforms and ship hulls (Figure 2) [61]. In marine aquaculture, biofouling is a major problem and expense factor, whose damage includes both the target culture species and/or cultivation infrastructure, which are exposed to a diverse array of fouling organisms with significant production impacts [62]. For example, in shellfish aquaculture, the key impact is the direct fouling of stock causing physical damage [63,64], mechanical interference [65], biological competition and environmental modification $[48,66,67]$, while infrastructure is also impacted. Regarding finfish aquaculture, biofouling affects infrastructure causing restriction of water exchange [68], which increases disease risk [69] and causes deformation of cages and structures [67]. For example, the hydroid Ectoleura larynx (syn. Tubularia larynx) is already one of the most common and troublesome biofouling species for Norwegian finfish aquaculture [70].

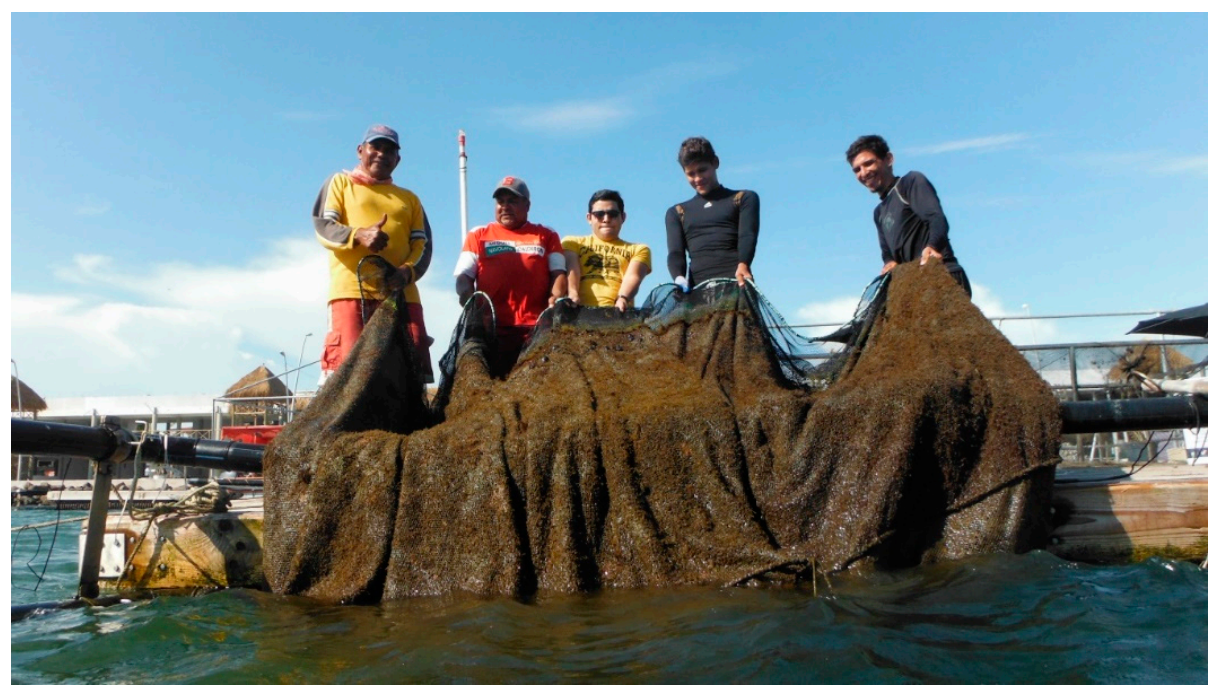

Figure 2. Marine aquaculture cage nets brittle from biofouling, Altata, Sinaloa, Mexico.

The direct economic cost of biofouling control to the aquaculture industry is substantial, with conservative estimates of $5 \%-10 \%$ of production costs attributed to biofouling. Globally, this equates to a cost of US $\$ 1.5$ to 3 billion per year [71]. The impact of biofouling is highly detrimental to the cost-effective production of fish and shellfish in marine aquaculture [72]. The control of biofouling in aquaculture is achieved through the avoidance of natural recruitment [73], physical removal [74] and the use of antifoulants [75,76]. Frequent net cleaning damages the mesh, stresses the animals and the eventual replacement of nets increases costs and thus decreases profit margins [76]. The use of chemical antifoulants that contain biocides such as cuprous oxide, copper isothianate, copper pyrithione, zinc pyrithione and zinc oxide ECONIA paints have proven effective on nets, but their use is undesirable because of environmental effects from broad-spectrum, metal-based toxins, together with consumer concerns, which can damage market image [76,77].

There is an urgent need to develop improved, less toxic means of controlling biofouling of surfaces in marine environments, both because of increasingly restrictive environmental regulations, such as the ban on tributyltin paints [78] and the high costs of registration of antifouling paints [79]. Considering the key role that biofilms appear to play as primary colonizers, in the adhesion of biofouling communities (plants and animals), it seems a reasonable strategy to search for novel 
compounds exhibiting antifouling activity against dominant members of biofilms. Furthermore, since EPS mediate the irreversible attachment of microorganisms to surfaces, the search of natural compounds that interfere with EPS adhesion (including other EPS) would be useful in providing insight into the molecular mechanisms of microbial adhesion to inert surfaces (metals, polymers, etc.). In this connection, in a preliminary study, extracellular polysaccharide formulations purified from marine bacteria as potential antifouling agents were evaluated [80]. EPS from Alteromonas, Pseudomonas, and Vibrio spp. inhibited preliminary biofouling (primarily, bacteria) over the test period. None of the formulations evaluated showed any evidence of antimicrobial activity or cytotoxicity. Another EPS with anti-biofilm activity (preliminary to biofouling) was isolated from marine bacterium Oceanobacillus iheyensis BK6 and exhibited activity against a former biofilm strain of Staphylococcus aureus [81]. S. aureus has been reported as inhabiting a marine recirculating aquaculture system [82]. Similarly, a marine bacterium Marinobacter litoralis was isolated for its ability to produce extracellular lipopolysaccharide, which has shown inhibitory activity towards swarming motility and biofilm formation by Pseudomonas aeruginosa [83], a model study bacterium for anti-biofilm activity on industrial surfaces. Also, anti-adhesive and anti-settlement activity toward marine invertebrates has been shown. In a study, the antiadhesive potential of extracellular proteases of Pseudoalteromonas issachenkonii UST041101-043 against bryozoans was demonstrated [84]. Given that EPS of biofilms are considered adhesion promoters for marine invertebrates [85], there are few scientific publications dealing with evaluation of their antifouling properties. However, there is a clear potential for the use of bacterial EPS for antifouling purposes. For example, EPS used in the form of permanent coating or grafted to other organic films may affect biofilm formation by preventing bacterial adhesion on marine surfaces by modifications of their physical characteristics [81]. Another advantage is that EPS do not contain toxic heavy metals or other molecules harmful to the marine environment.

\subsection{Enhancement of Colonization of Aquaculturally Valuable Larvae by EPS}

Microbial colonization is a process that represents one of the most crucial and complex stages in the life cycle of marine invertebrates, not only with regard to biofouling, but also critically important in aquaculture for increasing the percentage of larval settlement and metamorphosis [85]. An issue tightly coupled with biofouling, is the potential of using selected EPS to promote enhanced colonization of substrata by larvae of organisms in aquaculture. Although related, this is a seldomly researched topic, although the relevance for aquaculture appears obvious. In this regard, it is important to note that chemical cues play a pivotal role in invertebrate settlement. A variety of chemical cues of microbial, plant and animal origin mediate the settlement process. For this reason, many studies have been conducted to evaluate the potential of a variety of chemical cues to enhance settlement of marine invertebrates in aquaculture. For example, one study evaluated chemical cues (natural biofilm and macroalgae) to enhance settlement of the sea urchin Tripneustes gratilla [86]. Macroalgae-conditioned seawater combined with natural biofilm induced significantly higher settlement than to the biofilm alone. In a similar study, the larval settlement of the common Australian sea urchin Heliocidars erythrogramma was evaluated in response to bacteria from the surface of coralline algae [87]. The results, through molecular and culture-based analyses, suggested that the biofilm on plants was important for significant settlement. Microbial biofilms may provide inductive cues that identify attractive substrata for larval settlement [88] and this is perhaps explained, at least partially, by EPS. Chemical cues can be surface-bound EPS of bacterial biofilms or water-soluble EPS produced by both planktonic bacteria and biofilms [89]. For example, specific bacterial (Halomonas sp.)—microalgal (Amphora sp.) biofilms were effective for promoting the larval settlement of Argopecten purpuratus (Lamarck, 1819) on artificial spat-collecting materials [90]. Also, larval settlement and metamorphosis of Pinctada fucata, a species of great value in the hatchery industry, was demonstrated in response to natural biofilms [91]. The authors found that these processes were influenced by the biofilm community structure and extracellular products rather than the microbial abundance. Recently, the effect of natural biofilms on settlement of plantigrades of Mytilus coruscus, an important aquaculture 
species in China [92], was demonstrated. Plantigrades settled in response to natural biofilms, the percentage of plantigrade settlement being related to biofilm age and presence of EPS. This also appears to be the case for Bugula neritina, a marine-fouling organism with high economic value in aquaculture for the production of antineoplasic agents $[93,94]$. Furthermore, the influence of EPS on settlement of seaweeds has also been documented. In this regard, an EPS secreted by the endophytic bacterium Bacillus flexus (GU592213) facilitated the primary settlement of zoospores of Ulva fasciata [95]. $U$. fasciata is the commercial source of a biopolymer with binding properties used to manufacture certain aquaculture feeds [96]. However, EPS alone do not necessarily imply facilitated settling of organisms. For example, Patil and Anil [97] found a positive influence of diatom exopolymers combined with bacterial biofilms on metamorphosis of the barnacle Balanus amphitrite, but an opposite influence when EPS were tested alone [98].

Chemical cues that signal habitat and illicit larval settlement are a common denominator for a wide range of sessile marine taxa with settlement initiated in response to conspecifics, host organisms and microbial biofilms. For aquaculture, this is a developing field of research that requires maturing before reproducibility in performance of technologies is attained. At present, studies on the chemical cues of the tropical sponge Rhopaloeides odorabile $[99,100]$ represent the first step toward assessment of the aquaculture potential of marine invertebrates.

Ocean acidification $(\mathrm{OA})$, a recently recognized phenomenon of global concern, may negatively influence the settling of aquaculturally valuable marine invertebrates. The increase of atmospheric $\mathrm{CO}_{2}$ concentrations has led to higher levels of $\mathrm{CO}_{2}$ in the oceans, yielding as a consequence an altered state of the carbon seawater chemistry and reduction of $\mathrm{pH}[101,102]$. These changes affect directly the marine organisms that possess carbonate structures such as shells and spicules. An indirect and not obvious impact may also take place due to OA by negatively altering early stages of settling [103]. This influence may be related to $\mathrm{pH}$ shifts that induce changes of signaling molecules needed for settlement [104-106]. In this sense, it has been observed that OA may induce shifts in microbial communities [104,105]. These changes may not only alter the composition of microbial communities, a factor that plays a role in affecting the settlement of invertebrates [106,107], but also alter the conformational state and calcium-binding properties of marine microorganisms [108]. Both changes in microbial diversity and EPS biofilms could cause ecosystem alterations, and these alterations may affect the ecosystem of economical valuable species [109,110].

\subsection{EPS-Based Flocculation with Potential in Waste Treatment Processes of Coastal Aquaculture}

Coastal zones are prone to environmental impact and contamination due to urban development and other human activities. These include but are not restricted to habitat loss and/or modification, excessive harvesting of wild seed/spawners, introduction of exotic species, unintended release of cultured animals, spread of diseases, deleterious interactions with wild populations, misuse of chemicals and antibiotics, and release of wastes [1,111-113]. The release of wastes is perhaps one of the most relevant impacts affecting coastal ecosystems. Wastes entering coastal zones contain a variety of harmful substances including biological contaminants, such as pathogenic microorganisms (i.e., viruses, bacteria and protozoans) and organic matter (i.e., nitrates, phosphates); persistent organic compounds (i.e., organochlorines and polycyclic aromatic hydrocarbons) and other pollutants (i.e., heavy metals, plastic debris and nanoparticles) [114-116]. Wastes entering the coastal zones can occur as suspended particles (larger than $100 \mu \mathrm{m}$, e.g., sludge), colloids (0.001-1 $\mu \mathrm{m}$ e.g., organic and inorganic pollutants, proteinaceous materials, some algae, and bacteria) and dissolved molecules (smaller than $0.001 \mu \mathrm{m}$ e.g., individual molecules or ions) [117-119]. Removal of particles in aquaculture is critical for maintaining culture water quality in closed systems [117], and for minimizing interactions of environmental contaminants with biota in open systems, as they may induce shifts in phytoplankton and zooplankton communities, thus altering food webs and biogeochemical processes that can potentially affect cultured species in cages $[120,121]$. 
Wastewater from aquaculture (mainly intensive land-based aquaculture) contains considerable amounts of nitrogen, phosphorous and organic carbon [120,122]. The most common solid-removal units used for aquaculture are settling basins that are based on separation by gravity, hydrocyclones or swirl separators, which allows more rapid separation of the particles from the liquid, microscreen filters that are based on screening particles that are larger than the screen's mesh size, and granular/porous media filters that are based on the passage of water through a medium on which the solids are deposited [123]. After their removal, the concentrated solids are usually discharged from the recirculating aquaculture system either into receiving water bodies, the local sewer system, or a decentralized treatment unit, most commonly waste-stabilization ponds (WSPs) [123].

Disposal of aquaculture sludge into wastewater-treatment systems is often prohibited as it usually involves high volumes with high organic matter content and/or salts that might interfere with the treatment of municipal sludge. The activated sludge process is the most common biological process that is used in wastewater treatment. Sludge flocculation transforms microbial cells into aggregates, which regulates the performance of biomass-water separation and is thus crucial to the overall treatment result of the activated sludge process [124]. EPS are present in varying quantities in sludge and are thought to be of considerable importance in the removal of pollutants from wastewater, in bioflocculation and settling, and in the dewatering of activated sludge [125]. Flocculation is one of the most widely used processes for the removal of suspended and dissolved solids, colloids and organic matter present in industrial wastewater [126]. In this process, after the addition of coagulant and/or flocculant, finely divided or dispersed particles are aggregated or agglomerated together to form large particles of such a size (flocs) that they settle and thus clarify the system [127]. Up to now, a wide range of flocculants have been developed or designed to improve the flocculation process in wastewater treatment, including synthetic or natural organic flocculants. Natural organic flocculants, or bioflocculants (i.e., bacterial EPS), have emerged as promising alternative materials to replace conventional flocculants because they are safe and biodegradable and produce no secondary pollution [122], and thus may be applied for aquaculture purposes. Due to their physical-chemical properties, EPS displaying flocculant activity can destabilize the colloidal particles by increasing the ionic strength and giving some reduction in the zeta potential and thus a decreased thickness of the diffused part of the electrical double layer. Alternatively, they could specifically adsorb counterions to neutralize the particle charge because they have particular macromolecular structures with a variety of functional groups that can interact with contaminants [53,128]. There is a large number of publications related to EPS as flocculants in industrial processes such as wastewater treatment, downstream processing and food and fermentation processes $[51,129,130]$, but no reference, to our knowledge, of marine aquaculture system applications.

\subsection{Interactions of EPS-Contaminants in Coastal Aquaculture Systems}

Advancement of science during the last ten years has improved our understanding of interactions between microbial EPS and contaminants. It is documented that microorganisms participate in metal binding in coastal areas primarily through excretion of siderophores, organic acids and enzymes [131], but their role in metal binding by releasing EPS is less well understood. For example, in one study, the role of EPS as carriers of heavy metals in the marine food chain was demonstrated. Copper and lead bacterial EPS complexes were given to the benthic polychaete Hediste diversicolor as feed. EPS were shown to serve as effective natural organic ligands binding dissolved copper and lead at a range of concentrations and $\mathrm{pH}$ values, suggesting this route can concentrate metals through the marine food chain [132]. Other cultured benthic deposit-feeders such as sea cucumbers, may also concentrate metals, although this may vary given that various factors influence metal sorption by EPS, including metal concentration, incubation time, $\mathrm{pH}$ and salinity of the medium. Another interaction that should be considered in coastal aquaculture relates to pathogen transmission. It has been shown that EPS can promote transmission of terrestrially derived pathogens. In a study, the zoonotic parasite Toxoplasma gondii was used as a model to evaluate EPS-mediated mechanisms that promote 
transmission of this pathogen to marine fauna and humans. Transparent exopolymers were shown to enhance T. gondii association with marine aggregates, and EPS-derived from biofilms on macroalgae also captured T. gondii from the water [133]. On the other hand, natural organic matter (NOM) has an important effect by trapping metals via the carboxyl groups in NOM $[134,135]$. Higher rates of metal trapping by sinking NOM may occur in aquaculture areas as a biogeochemical consequence of eutrophication, which is a phenomenon seldom acknowledged. In addition, sedimentary microorganisms may also contribute significantly to NOM in coastal areas. It can be hypothesized that EPS representing an important fraction of sedimentary natural organic matter may be relevant in coastal aquaculture. The EPS can transport NOM through the water column. The influence of bacterial EPS composition and quantity on the biosorption of natural organic matter (NOM) has been shown in research using two bacterial species (Pseudomonas aeruginosa and Pseudomonas putida) [135]. $P$. aeruginosa produced an EPS with polysaccharides as the primary component, whereas $P$. putida produced protein-based EPS. The results indicated that the composition and quantity of the EPS had a profound impact on biosorption, which corresponded to an increased presence of carboxyl groups in polysaccharide-based EPS of $P$. aeruginosa for bridging with the carboxyl groups on the NOM. Carboxyl content in both EPS and NOM appeared to be linked to increased biosorption via bridging with divalent ions. Divalent ion concentrations in the aquatic environment will promote biosorption processes, permitting functional group interactions between EPS and NOM. Likewise, the implications of biofilms in metal pollution derived from fish farming [136] has been examined. It was found that fish feed waste enhanced the accumulation of organic matter and metal contamination in biofilm communities, suggesting the role of biofilms as a sink for contaminants, with implications for metal transfer in the cultured species and surrounding coastal habitats. Interestingly, biofloc technology (BFT) has been considered as a key method for increasing the aquaculture activity and improving the immunostatus of the organisms. It is commonly believed that closed systems conserve water and reduce pollution problems. Biofloc technology has been considered as a novel ecological technique used to reduce nitrogen concentration and remove pollutants. As far as we are aware, there is no study describing the potential of bioflocs as reservoirs of pollutants and their ability of transferring them to cultured organisms. Since biofilms are an important issue in the fields of marine science, several microbial ecology studies are needed to better understand their role as bioindicators for aquaculture in coastal zones.

\subsection{EPS Associated with Phytoplankton Blooms Influence Coastal Aquaculture}

Naturally occurring phytoplankton blooms have been responsible for serious problems of aquaculture, fisheries and public health in many coastal waters throughout the world [137,138]. These proliferations are termed harmful algal blooms (HABs) [139]. HABs may disrupt ecosystems by either producing specific toxins or by causing anoxia during the decay process of settled algal biomass and by physical interferencing with gases exchange when clogging the gills of fishes and filter-feeding animals [137-139]. Marine aquaculture activities have been affected worldwide by phytoplankton blooms, including cultured species such as mussels in Spain and Germany, and fish farms in China [140-142]. Recent HAB events in 2016 affecting salmon farms in Chile exemplify the threat of HABs towards marine aquaculture. HABs occur when environmental conditions are adequate for algal proliferation and when high levels of nutrients are released into the coastal zone [142]. It is known that EPS are released when high densities of phytoplankton are reached, a phenomenon also seen in closed systems [20]. There is scarce information regarding the role of EPS in HAB occurrence and their impact on cultured species. Some studies, however, suggest that EPS associated with HAB-producing species may contribute to their persistence or impact on phytoplankton and zooplankton communities serving as food for cultured species [143]. In a previous study, it was shown that the polysaccharide-protein EPS produced by Heterosigma akashiwo, a typical HAB species, inhibited the growth of co-ocurring aquaculturally relevant phytoplankton species such as Skelotonema costatum and Thalassiosira rotula. Furthermore, these EPS stimulated the growth of $H$. akashiwo and other 
harmful dinoflagellates, Prorocentrum spp. and Heterocapsa circularisquama [144]. This suggests that EPS may facilitate the persistence of $H$. akashiwo and other HAB species both through direct stimulation and indirectly, aiding to outcompete other phytoplankton species. These biomolecules could help $H$. akashiwo succeed in establishing dense cyst beds, which give the next generation an advantage by allowing extensive reinoculation of the water column. On the other hand, the release of EPS by non-toxic marine phytoplankton species may have consequences on aquaculture, as exemplified by the marine phytoplankton Phaeocystis spp., which excretes polysaccharides, forming TEP. It has been shown that TEP could serve as a food source, which would imply a positive effect in aquaculture. However, a study observed a decrease of the feeding rates of copepods and euphausiids in the presence of polysaccharides excreted by Pheaocystis sp. [145]. Taken together, these studies suggest that under real conditions $\mathrm{HAB}$ populations and non-toxic phytoplankton communities could release EPS that may pose a negative impact on marine aquaculture, an implication that has not been highlighted before. Further studies are required to determine if the impact of EPS occurs at the global scale.

\subsection{EPS-Based Products for Aquaculture Applications}

The increased demand for natural polymers for various industrial applications in recent years has led to a renewed interest in the search for novel EPS. Various microbial EPS possess novel and unique properties that have found applications in the food, pharmaceutical, biomedical and cosmetic fields [146]. Their usefulness is mostly related to their properties as thickening, stabilizing, binding and structure-creation agents [147]. Physical and dynamic properties displayed by EPS such as adsorption, viscosity, solubility and biodegradability depend upon their macromolecular composition (polysaccharides, proteins, lipids, nucleic acids, humic substances) and structural conformation $[147,148]$. Based on these properties, EPS may find applications as biotechnological products in aquaculture as bioemulsifiers, biosurfactants, biosorbents, bioflocculants, foods, antifouling agents, antivirals, immunostimulants and immunomodulators [148-150] as discussed below.

Point sources of pollutants such as excess nutrients, hazardous organics, heavy metals, hydrocarbons and nanoparticles affect marine aquaculture activities [151,152]. For example, petroleum from accidental oil spills has been reported near active aquacultural areas [153]. EPS-based products may aid in developing bioremediation strategies for accidental spills of hydrocarbons as EPS emulsifying and surfactant activities may help in their biodegradation. An EPS synthesized by the marine strain Microbacterium sp. MC3B-10 was characterized previously to have surfactant activity against aliphatic hydrocarbons and hinted at a potential metal-binding activity [154]. This EPS was termed microbactan and was extensively characterized [155]. Bioassay-based toxicity testing showed that microbactan is not toxic. Microbactan emulsified aromatic hydrocarbons and oils to various extents. The stability of the emulsion in the model reached its highest level $(94 \%)$ at $50{ }^{\circ} \mathrm{C}, \mathrm{pH} 10$ and $3.5 \% \mathrm{NaCl}$ content, which sets similar conditions in marine aquaculture. Also, Gutierrez et al. [156] characterized two EPS from a marine Halomonas species. Purification and chemical analysis revealed both EPS to be glycoproteins of high molecular weight with emulsifying activity against hydrocarbons under neutral and acidic $\mathrm{pH}$ conditions.

Metal-binding properties of EPS could be applied in aquaculture activities. For example, EPS produced by Halomonas sp. TG39 have metal-binding properties and mediate their bioavailability to eukaryotic phytoplankton [157]. This was demonstrated through experiments employing Fe-limited growth conditions for the marine diatom Thalassiosira weissfloggii, which has been widely used as live feed in aquaculture [158]. Likewise, Hassler et al. [159] evaluated the role of EPS of Pseudoalteromonas sp.; a common marine bacterium, in iron speciation, solubilization and bioavailability for phytoplankton species. This study was the first to demonstrate iron interaction with natural EPS under conditions that are relevant to iron-limited marine regions. They found that the presence of EPS decreased Fe precipitation and increased Fe concentrations in solution. Analysis of bioavailability of the Fe-EPS complexes with Chaetoceros sp. CS 624 and Phaeocytis sp. CS243 showed that Fe-EPS complexes were strongly bioavailable, with only a three-fold decreased bioavailability as compared to inorganic 
Fe. This effect of EPS on the solubility and bioavailability of iron can increase the residence time of bioavailable iron in the euphotic zone and therefore increase primary productivity. This increased primary production may benefit aquaculture in coastal areas because EPS could improve nutrient uptake rather than increase the amount of food.

As already covered, EPS induce flocculation and this may find a novel biotechnological application in marine aquaculture. In microalgal aquaculture, flocculation and flotation are two efficient biomass harvesting techniques. The flotation technique occurs when air or gas is transformed into bubbles through a solid/liquid suspension; as a result, solid particles get attached to gaseous molecules and are carried up and accumulated on the surface [160]. In flocculation, the dispersed microalgal cells aggregate and form larger particles with a higher sedimentation rate. Flocculation can be induced either by chemicals (i.e., $\mathrm{Zn}^{2+}, \mathrm{Al}^{3+}$ or $\mathrm{Fe}^{3+}$ ) or biological flocculants (i.e., EPS, cellulose, chitosan) [161]. For example, harvesting of the marine microalga Nannochloropsis oceanica DUT01 by flocculation with EPS produced by Solibacillus silvestris isolate W01 has been evaluated. The EPS showed a 90\% flocculating efficiency on N. oceanica and no metal ion was required for the flocculation process [150]. Harvesting of the microalga Chlorella vulgaris was tested via flocculation-flotation with EPS produced by Cobetia marina L03 [162]. The results indicated that the bioflocculant from C. marina L03 could be used to effectively harvest C. vulgaris via flotation. They observed a flotation efficiency of over $90 \%$ when $20 \mathrm{mg} \cdot \mathrm{L}^{-1}$ EPS was tested for flocculating the microalgal cells with $5 \mathrm{mM} \mathrm{CaCl}$. This bioflocculant was stable over a range of $\mathrm{pHs}(6-8)$ and temperatures $\left(10-40^{\circ} \mathrm{C}\right)$, which is a harvesting advantage for cost-effective production of microalgal bioproducts. The use of microalgal bacterial flocs in sequential batch reactors is a novel approach used for aquaculture wastewater treatment [163,164]. Microalgal bacterial flocs are aggregations of microalgae and bacteria, and because of their larger size, they settle quickly by gravity. Also, another strategy for finding effective EPS is the screening of flocculants produced by bacteria isolated from bioflocs in aquaculture systems [165].

Finally, antiviral and immunomodulatory properties of EPS against salmonid viruses have been established [149]. Dextrans synthesized by Lactobacillus sakei MN1 and Leuconostoc mesentetoroides RTF10 were evaluated in infected BF-2 and EPC fish cell-line monolayers for antiviral activity [146]. In vivo assays using dextran of L. sakei MN1 confirmed antiviral activity and immunomodulatory activity. These results indicate the compound's potential utility as an antiviral agent in aquaculture. Similarly, microbial levan is widely used in aquaculture as food and immunostimulant [166]. A novel potential application of EPS is the proposal for a formulation of a marine antimicrobial and bacterial polysaccharides to increase cultured pearl production after bacterial pathogenesis [167]. The authors found that while the antimicrobial controls the bacteria, the EPS function as biobarrier filming agents, covering the damaged tissue. Table 1 provides a list of microbial EPS with potential applications in aquaculture systems.

Table 1. Microbial EPS with applications in aquaculture systems.

\begin{tabular}{|c|c|c|c|}
\hline EPS & Microorganism & Application & Reference \\
\hline Levan & Bacillus megaterium 1 & $\begin{array}{l}\text { Immunomodulatory in Cyprinus carpio fry } \\
\text { (Linnaeus 1758) exposed to fipronil }\end{array}$ & [169] \\
\hline Glucan & Paenibacillus polymyxa JB115 & Feed additive immunomodulator & {$[171]$} \\
\hline EPS & Solibacillus silvestris W01 & $\begin{array}{l}\text { Bioflocculant for harvesting of marine microalga } \\
\text { Nannochloropsis oceanica }\end{array}$ & [150] \\
\hline
\end{tabular}




\section{Conclusions}

Microorganisms occur in natural habitats and colonize aquaculture facilities in the coastal zone. They occupy major coastal habitats at interfaces of air-seawater (microbial neuston), seawater-sediment (microphytobenthos), hard bottoms (epilithic biofilms) or growing suspended in the water column in microbial cellular aggregates. Key constituents of such microbial communities are the extracellular polymeric substances (EPS) matrices that mediate processes relevant to coastal aquaculture settings. EPS have both beneficial and detrimental impacts on aquaculture systems such as marine cage aquaculture, shellfish farms and shore-based systems cultivating marine species. Detrimental roles played by EPS include the initial biofouling of marine cages, the bioconcentration of pollutants in coastal habitats where aquaculture activities take place, and increasing the residence and impact of harmful algal blooms. EPS play beneficial roles by sustaining valuable processes in bioflocculation, enhancing larval settlement of aquaculture-relevant species and as antivirals and immunostimulants. Potential biotechnological applications of EPS in marine aquaculture include the development of novel antifouling agents and development of a combined treatment with marine antimicrobials to increase survival of mollusks.

Future research avenues need to be explored to advance our current understanding of this field. Further work needs to be carried out in order to determine the chemistry and functional properties of naturally occurring EPS. Also, the potential of EPS to interfere with the irreversible attachment of microorganisms to surfaces and subsequent biofouling needs to be studied in detail to provide an insight into the molecular mechanisms of microbial adhesion to inert surfaces with relevance to aquaculture, which is of paramount importance to develop novel antifoulants. The biotechnological potential of EPS as promotors of attachment of commercial larvae is still in an early stage of research; before reproducibility can be achieved, the technology needs to be refined. Finally, in order to determine at quantitative levels the interaction of selected pollutants on EPS and microbial flocs, mesocosm studies mimicking the coastal environment are required to determine the pathways of pollution transport, partition and ultimate fate, using model organisms of aquaculture relevance.

Acknowledgments: Juan Carlos Camacho-Chab is funded by Ph.D. grant provided by Programa para el Desarrollo Profesional Docente PRODEP of SEP. The authors are grateful to Elías García-Lopez for the fine illustration and to Alfredo Emmanuel Vazquez Olivares for providing the picture of biofouled nets. We also thank John van der Meer for help with English editing. Comments and suggestions from anonymous reviewers helped to improve our manuscript.

Author Contributions: Juan Carlos Camacho-Chab and Benjamín Otto Ortega-Morales gathered data and reference papers, analyzed information and wrote this paper. Benjamín Otto Ortega-Morales also provided the overall focus of the review study. Fabiola Lango-Reynoso, María del Refugio Castañeda-Chávez, Itzel Galaviz-Villa and Demian Hinojosa-Garro assisted information analysis and contributed to writing of the manuscript.

Conflicts of Interest: The authors declare no conflict of interest.

\section{Abbreviations}

The following abbreviations are used in this manuscript:

EPS Extracellular polymeric substances

TEP Transparent exopolymer particles

OA Ocean acidification

DOM Dissolved organic matter

SML Sea-surface microlayer

WSPs Waste-stabilization ponds

NOM Natural organic matter

BFT Biofloc technology

HABs Harmful algal blooms

\section{References}

1. Martínez, M.L.; Intralawan, A.; Vazquez, G.; Pérez-Maqueo, O.; Sutton, P.; Landgrave, R. The coasts of our world: Ecological, economic and social importance. Ecol. Econ. 2007, 63, 254-272. [CrossRef] 
2. Schwartz, M.L. (Ed.) Encyclopedia of Coastal Science; Springer-Verlag: Houten, The Netherlands, 2005.

3. Ortega-Morales, B.O.; Chan-Bacab, M.J.; De La Rosa-García, S.; Camacho-Chab, J.C. Valuable processes and products from marine intertidal microbial communities. Curr. Opin. Biotechnol. 2010, 21, 346-352. [CrossRef] [PubMed]

4. Costanza, R.; d'Arge, R.; de Groot, R.; Farber, S.; Grasso, M.; Hannon, B.; Naeem, S.; Limburg, K.; Paruelo, J.; O'Neill, R.V.; et al. The value of the world's ecosystem services and natural capital. Nature 1997, 387, 253-260. [CrossRef]

5. Naylor, R.; Goldburg, R.; Primavera, J.; Kautsky, N.; Beveridge, M.; Clay, J.; Folke, C.; Lubchenco, J.; Mooney, H.; Troell, M. Effect of aquaculture on world fish supplies. Nature 2000, 405, 1017-1024. [CrossRef] [PubMed]

6. Food and Agriculture Organization of the United Nations (FAO). The State of World Fisheries and Aquaculture: Opportunities and Challenges; FAO: Rome, Italy, 2014.

7. Lucas, J.; Southgate, P. (Eds.) Aquaculture: Farming Aquatic Animals and Plants, 2nd ed.; Wiley-Blackwell: Oxford, UK, 2012.

8. Halliday, E.; Gast, R. Bacteria in beach sands: An emerging challenge in protecting coastal water quality and bather health. Environ. Sci. Technol. 2011, 45, 370-379. [CrossRef] [PubMed]

9. Munn, C. Marine Microbiology. Ecology and Applications, 2nd ed.; Garland Science-Taylor \& Francis Group: New York, NY, USA, 2012.

10. Martínez-Córdoba, L.R.; Emerenciano, M.; Miranda-Baeza, A.; Martínez-Porchas, M. Microbial-based systems for aquaculture of fish and shrimp: An updated review. Rev. Aquac. 2014, 6, 1-18.

11. Decho, A.W. Microbial biofilms in intertidal systems: An overview. Cont. Shelf Res. 2000, 20, 1257-1273. [CrossRef]

12. Flemming, H.C.; Wingender, J. The biofilm matrix. Nat. Rev. Microbiol. 2010, 8, 623-633. [CrossRef] [PubMed]

13. Franklin, M.; McDonald, I.; Bourne, D.; Owens, N.; Upstill-Goddard, D.; Colin, J. Bacterial diversity in the bacterioneuston (Sea surface microlayer): The bacterioneuston through the looking glass. Environ. Microbiol. 2005, 7, 723-736. [CrossRef] [PubMed]

14. Rooney-Varga, J.N.; Giewat, M.; Savin, M.C.; Sood, S.; LeGresley, M.; Martin, J.L. Links between phytoplankton and bacterial community dynamics in a coastal marine environment. Microb. Ecol. 2005, 49, 163-175. [CrossRef] [PubMed]

15. Wahl, M.; Goecke, F.; Labes, A.; Dobretsov, S.; Weingberger, F. The second skin: Ecological role of epibiotic biofilms on marine organisms. Front. Microbiol. 2012, 3, 1-21. [CrossRef] [PubMed]

16. Bar-Zeev, E.; Berman-Frank, I.; Girshevitz, O.; Berman, T. Revised paradigm of aquatic biofilm formation facilitated by microgel transparent exopolymer particles. Proc. Natl. Acad. Sci. USA 2012, 109, 9119-9124. [CrossRef] [PubMed]

17. Passow, U. Production of transparent exopolymers particles (TEP) by phyto-and bacterioplankton. Mar. Ecol. Prog. 2002, 236, 1-12. [CrossRef]

18. Passow, U. Transparent exopolymers particles (TEP) in aquatic environment. Prog. Oceanogr. 2002, 55, 287-333. [CrossRef]

19. Bhaskar, P.V.; Grossart, H.P.; Bhosle, N.B.; Simon, M. Production of macroaggregates from dissolver exopolymeric substances (EPS) of bacterial and diatom origin. FEMS Microbiol. Ecol. 2005, 53, 255-264. [CrossRef] [PubMed]

20. Joyce, A.; Utting, S. The role of exopolymers in hatcheries: An overlooked factor in hatchery hygiene and feed quality. Aquaculture 2015, 446, 122-131. [CrossRef]

21. Watnick, P.; Kolte, R. Biofilm, city of microbes. J. Bacteriol. 2000, 182, 2675-2679. [CrossRef] [PubMed]

22. Costerton, J.W.; Geesey, G.G.; Cheng, K.J. How bacteria stick. Sci. Am. 1978, 238, 86-95. [CrossRef] [PubMed]

23. Flemming, H.C.; Wingender, J. Relevance of microbial extracellular polymeric substances (EPSs)-Part I: Structural and ecological aspects. Water Sci. Technol. 2001, 43, 1-8. [PubMed]

24. Donlan, R.M. Biofilms: Microbial life on surfaces. Emerg. Infect. Dis. 2002, 8, 881-890. [CrossRef] [PubMed]

25. Chang, Y.W.; Fragkopoulos, A.; Marquez, S.; Kim, H.; Angelini, T.E.; Fernández-Nieves, A. Biofilm formation in geometries with different surface curvature and oxygen availability. New J. Phys. 2015, 17. [CrossRef]

26. De Beer, D.; Stoodley, P. Microbial biofilms. In The Prokaryotes, 1st ed.; Rosenberg, E., Ed.; Springer-Verlag: Berlin/Heidelberg, Germany, 2013; pp. 343-372.

27. Ivanov, V. Monitoring the bacterial neuston. Rapid Methods Anal. Biol. Mater. Environ. 2000, 30, 67-72. 
28. Pisman, T.I.; Galayda, Y.V.; Loginova, N.S. Population dynamics of an algal-bacterial cenosis in closed ecological system. Adv. Space Res. 2005, 35, 1579-1583. [CrossRef] [PubMed]

29. Wurl, O.; Holmes, M. The gelatinous nature of the sea-surface microlayer. Mar. Chem. 2008, 110, 89-97. [CrossRef]

30. Wahl, M. Marine epibiosis. I. Fouling and antifouling: Some basic aspects. Mar. Ecol. Prog. Ser. 1989, 58, 175-189. [CrossRef]

31. Larned, S. A prospectus for periphyton: Recent and future ecological research. J. N. Am. Benthol. Soc. 2010, 29, 182-206. [CrossRef]

32. Arnon, S.; Packman, A.I.; Peterson, C.G.; Gray, K. Effects of overlying velocity on periphyton structure and denitrification. J. Geophys. Res. Atmos. 2007, 112, 1-10. [CrossRef]

33. Richard, M.; Maurice, J.T.; Anginot, A.; Paticat, F.; Verdegem, M.C.; Hussenot, J.M. Influence of periphyton substrates and rearing density on Liza aurata growth and production in marine nursery ponds. Aquaculture 2010, 310, 106-111. [CrossRef]

34. Michael, T.S.; Shin, H.W.; Hanna, R.; Spafford, D.C. A review of epiphyte community development: Surface interactions and settlement on seagrass. J. Environ. Biol. 2008, 29, 629-638. [PubMed]

35. Egan, S.; Harder, T.; Burke, C.; Steinberg, P.; Kjelleberg, S.; Thomas, T. The seaweed holobiont: Understanding seaweed-bacteria interactions. FEMS Microbiol. Rev. 2013, 37, 462-476. [CrossRef] [PubMed]

36. Tan, E.L.; Mayer-Pinto, M.; Johnston, E.L.; Dafforn, K. Differences in intertidal microbial assemblages on urban structures and natural rocky reef. Front. Microbiol. 2015, 6, 1276. [CrossRef] [PubMed]

37. Graba, M.; Sauvage, S.; Majdi, N.; Mialet, B.; Moulin, F.; Urrea, G.; Buffan-Dubau, E.; Tackx, M.; Sabater, S.; Sanchez-Pérez, J. Modelling epilithic biofilms combining hydrodynamics invertebrate grazing and algal traits. Freshw. Biol. 2014, 59, 1213-1228. [CrossRef]

38. Ortega-Morales, B.O.; Santiago-García, J.L.; López-Cortés, A. Biomass and taxonomic richness of epilithic cyanobacteria in a tropical intertidal rocky hábitat. Bot. Mar. 2005, 48, 116-121. [CrossRef]

39. De Schryver, P.; Crab, R.; Defoirdt, T.; Boon, N.; Verstraete, W. The basics of bio-flocs technology: The added value for aquaculture. Aquaculture 2008, 277, 125-137. [CrossRef]

40. Drudge, C.; Warren, L. Diurnal floc generation from neuston biofilms in two contrasting freshwater lakes. Environ. Sci. Technol. 2014, 48, 10107-10115. [CrossRef] [PubMed]

41. Kazemipour, F.; Méléder, V.; Launeau, P. Optical properties of microphytobenthic biofilms (MPBOM): Biomass retrieval implication. J. Quant. Spectrosc. Radiat. Transf. 2010, 112, 131-142. [CrossRef]

42. Carpintero de Moraes, P.; Castillo, D.; Helena, V.; Gomes, P. Effect of plankton-derived organic matter on the microbial community of coastal marine sediments. J. Exp. Mar. Biol. Ecol. 2014, 461, 257-266. [CrossRef]

43. Camps, M.; Barani, A.; Gregori, G.; Bouchez, A.; Le Berre, B.; Bressy, C.; Blache, Y.; Briand, J. Antifouling coatings influence both abundance and community structure of colonizing biofilms: A case study in the Northwestern Mediterranean Sea. Appl. Environ. Microbiol. 2014, 80, 4821-4831. [CrossRef] [PubMed]

44. Salta, M.; Wharton, J.; Blache, Y.; Stokes, K.; Stokes, K. Marine biofilms on artificial surfaces: Structure and dynamics. Environ. Microbiol. 2013, 15, 2879-2893. [CrossRef] [PubMed]

45. Zardus, J.D.; Nedved, B.T.; Huang, Y.; Tran, C.; Hadfield, M. Microbial biofilms facilitate adhesion in biofouling invertebrates. Biol. Bull. 2008, 214, 91-98. [CrossRef] [PubMed]

46. Hadfiel, M. Why and how marine-invertebrate larvae metamorphose so fast. Cell Dev. Biol. 2000, 11, 437-443. [CrossRef] [PubMed]

47. Rodríguez, S.; Ojeda, P.; Inestrosa, N. Settlement of benthic marine invertebrates. Mar. Ecol. Prog. Ser. 1993, 97, 193-207. [CrossRef]

48. Dobretsov, S.; Dahms, H.U.; Qian, P.Y. Inhibition of biofouling by marine microorganisms and their metabolites. Biofouling 2006, 22, 43-54. [CrossRef] [PubMed]

49. Bloecher, N.; Olsen, Y.; Guenther, J. Variability of biofouling communities on fish cage nets: A 1-year field study at a Norwegian salmon farm. Aquaculture 2013, 416-417, 302-309. [CrossRef]

50. Laspidou, C.S.; Rittmann, B.E. A unified theory for extracellular polymeric substances, soluble microbial products, and active and inert biomass. Water Res. 2002, 36, 2711-2720. [CrossRef]

51. Sheng, G.P.; Yu, H.Q.; Li, X.Y. Extracellular polymeric substances (EPS) of microbial aggregates in biological wastewater treatment systems: A review. Biotechnol. Adv. 2010, 28, 882-894. [CrossRef] [PubMed]

52. Flemming, H.C.; Neu, T.R.; Wozniak, D. The EPS Matrix: The "House of Biofilm Cells". J. Bacteriol. 2007, 189, 7945-7947. [CrossRef] [PubMed] 
53. Li, W.W.; Yu, H.Q. Insight into the roles of microbial extracellular polymer substances in metal biosorption. Bioresour. Technol. 2014, 160, 15-23. [CrossRef] [PubMed]

54. Mari, X.; Burd, A. Seasonal size spectra of transparent exopolymeric particles (TEP) in a coastal sea and comparison with those predicted using coagulation theory. Mar. Ecol. Prog. Ser. 1998, 163, 63-76. [CrossRef]

55. Vu, B.; Chen, M.; Crawford, R.; Ivanova, E.P. Bacterial extracellular polysaccharides involved in biofilm formation. Molecules 2009, 14, 2535-2554. [CrossRef] [PubMed]

56. Costerton, J.W.; Lewandowski, Z.; Caldwell, D.; Korber, D.; Lappin-Scott, H.M. Microbial biofilms. Ann. Rev. Microbiol. 1995, 49, 711-745. [CrossRef] [PubMed]

57. Tsuneda, S.; Aikawa, H.; Hayashi, H.; Yuasa, A.; Hirata, A. Extracellular polymeric substances responsible for bacterial adhesion onto solid surface. FEMS Microbiol. Lett. 2003, 223, 287-292. [CrossRef]

58. O'Toole, G.A.; Kaplan, H.; Kolter, R. Biofilm formation as microbial development. Ann. Rev. Microbiol. 2000, 54, 49-79. [CrossRef] [PubMed]

59. Costerton, J.W. Overview of microbial biofilms. J. Ind. Microbiol. Biotechnol. 1995, 15, 137-140. [CrossRef]

60. Hinojosa-Garro, D.; Mason, C.F.; Underwood, G. Influence of macrophyte spatial architecture on periphyton and macroinvertebrate community structure in shallow water bodies under contrasting land management. Fundam. Appl. Limnol. 2010, 177, 19-37. [CrossRef]

61. Abarzua, S.; Jakubowski, S.; Eckert, S.; Fuchs, P. Biotechnological investigation for the prevention of marine biofouling II. Blue-green algae as potential producers of biogenic agents for the growth inhibition of microfouling organisms. Bot. Mar. 1999, 42, 459-465. [CrossRef]

62. Guardiola, F.A.; Cuesta, A.; Meseguer, J.; Esteban, M.A. Risks of using antifouling biocides in aquaculture. Int. J. Mol. Sci. 2012, 13, 1541-1560. [CrossRef] [PubMed]

63. Silina, A.V. Tumor-like formations on the shells of Japanese scallops Patinopecten yessoensis. Mar. Biol. 2006, 148, 833-840. [CrossRef]

64. Simon, C.A.; Ludford, A.; Wynne, S. Spionid polychaetes infesting cultured abalone Haliotis midae in South Africa. Afr. J. Mar. Sci. 2006, 28, 167-171. [CrossRef]

65. Sá, F.; Nalesso, R.; Paresque, K. Fouling organisms on Perna Perna mussels: Is it worth removing them? Braz. J. Oceanogr. 2007, 55, 155-161. [CrossRef]

66. Lodeiros, C.; Pico, D.; Prieto, A.; Narvaez, N.; Guerra, A. Growth and survival of the Pearl oyster Pinctada imbricata (Roding 1758) in suspended and bottom culture in the Golfo de Cariaco, Venezuela. Aquac. Int. 2002, 10, 327-338. [CrossRef]

67. Ross, K.A.; Thorpe, J.P.; Norton, T.A.; Brand, A.R. Fouling in scallop cultivation: Help or hindrance? J. Shellfish Res. 2002, 21, 539-547.

68. Le Blanc, A.R.; Landry, T.; Miron, G. Fouling organisms of the blue mussel Mytilus edulis: Their effect on nutrient uptake and reléase. J. Shellfish. Res. 2003, 22, 633-638.

69. Jensen, Ø.; Dempster, T.; Thorstad, E.; Uglem, I.; Fredheim, A. Escapes of fish from Norwegian sea-cage aquaculture: Causes, consequences and prevention. Aquac. Environ. Interact. 2010, 1, 71-83. [CrossRef]

70. Guenther, J.; Carl, C.; Sunde, L.M. The effects of colour and copper on the settlement of the hydroid Ectopleura larynx on aquaculture nets in Norway. Aquaculture 2009, 292, 252-255. [CrossRef]

71. Lane, A.; Willemsem, P.R. Collaborative effort looks into biofouling. Fish Farming International, September 2004; pp. 34-35.

72. Fitridge, I.; Dempster, T.; Guenther, J.; de Nys, R. The impact and control of biofouling in marine aquaculture: A review. Biofouling J. Bioadhesion Biofilm Res. 2012, 28, 649-669. [CrossRef] [PubMed]

73. Willis, J.E.; Stewart-Clark, S.; Greenwood, S.J.; Davidson, J.; Quijon, P.A. A PCR-based assay to facilitate early detection of Diplosoma listerianum in Atlantic Canada. Aquat. Invasions 2011, 6, 7-16. [CrossRef]

74. Forrest, B.M.; Blakemore, K.A. Evaluation of treatments to reduce the spread of a marine plant pest with aquaculture transfers. Aquaculture 2006, 257, 333-345. [CrossRef]

75. Bond, P.R.; Brown, M.T.; Moate, R.M.; Gledhill, M.; Hill, S.J.; Nimmo, M. Arrested development in Fucus spiralis (Phaeophyceae) germlings exposed to copper. Eur. J. Phycol. 1999, 34, 513-521. [CrossRef]

76. Swain, G.; Shinjo, N. Comparing biofouling control treatments for use on aquaculture nets. Int. J. Mol. Sci. 2014, 15, 22142-22154. [CrossRef] [PubMed]

77. Hodson, S.; Burke, C.; Bisset, A. Biofouling of fish-cage netting: The efficacy of a silicone coating and the effect of netting colour. Aquaculture 2000, 184, 277-290. [CrossRef] 
78. Bell, G.M.; Chadwick, J. Regulatory controls on biocides in the United Kingdom and restrictions on the use of triorganotin-contaaining antifouling products. Int. Biodeterior. Biodegrad. 1994, 34, 375-386. [CrossRef]

79. Bingaman, W.W.; Willingham, G.L. The changing regulatory environment: EPA registration of a new marine antifoulant active ingredient. Int. Biodeterior. Biodegrad. 1994, 34, 387-399. [CrossRef]

80. Guezennec, J.; Herry, J.M.; Kouzayha, A.; Bachere, E.; Mittelman, M.W.; Bellon, M.N. Exopolysaccharides from unusual marine environments inhibit early stages of biofouling. Int. Biodeterior. Biodegrad. 2012, 66, 1-7. [CrossRef]

81. Kavita, K.; Kumar-Singh, V.; Mishra, A.; Jha, B. Characterisation and anti-biofilm activity of extracellular polymeric substances from Oceanobacillus iheyensis. Carbohydr. Polym. 2014, 101, 29-35. [CrossRef] [PubMed]

82. Michaud, L.; Lo Giudice, A.; Troussellier, M.; Smedile, F.; Bruni, V.; Blancheton, J.P. Phylogenetic characterization of the heterotrophic bacterial communities inhabiting a marine recirculating aquaculture system. J. Appl. Microbiol. 2009, 107, 1935-1946. [CrossRef] [PubMed]

83. Kumar-Sardar, R.; Kavita, K.; Jha, B. Lipopolysaccharide of Marinobacter litoralis inhibits swarming motility and biofilm formation in Pseudomonas aeruginosa PA01. Carbohydr. Polym. 2015, 123, 468-475. [CrossRef] [PubMed]

84. Dobretsov, S.; Xiong, H.; Xu, Y.; Levin, L.A.; Qian, P.Y. Novel antifoulants: Inhibition of larval attachment by proteases. Mar. Biotechnol. 2007, 9, 388-397. [CrossRef] [PubMed]

85. Hadfield, M.G. Biofilms and marine invertebrate larvae: What bacteria produce that larvae use to choose settlement sites. Annu. Rev. Mar. Sci. 2011, 3, 453-470. [CrossRef] [PubMed]

86. Mos, B.; Cowden, K.; Nielsen, S.; Dworjanyn, S. Do cues matter? Highly inductive settlement cues don't ensure high post-settlement survival in sea urchin aquaculture. PLoS ONE 2011, 6, e28054. [CrossRef] [PubMed]

87. Huggett, M.; Williamson, J.; de Nys, R.; Kjelleberg, S.; Steinberg, P. Larval settlement of the common Australian sea urchin Heliocidaris erythrogramma in response to bacteria from the surface of coralline algae. Oecologia 2006, 149, 604-619. [CrossRef] [PubMed]

88. Dahms, H.U.; Dobretsov, S.; Qian, P.Y. The effect of bacterial and diatom biofilms on the settlement of the bryozoan Bugula neritina. J. Exp. Mar. Biol. Ecol. 2004, 313, 191-209. [CrossRef]

89. Maitrayee, A.; Alfaro, A.; Brooks, J.; Higgins, C. The role of bacterial biofilms and exudates on the settlement of mussel (Perna canaliculus) larvae. Aquaculture 2010, 306, 388-392.

90. Leyton, Y.; Riquelme, C. Use of specific bacterial-microalgal biofilms for improving the larval settlement of Argopecten purpuratus (Lamarck, 1819) on three types of artificial spat-collecting materials. Aquaculture 2008, 276, 78-82. [CrossRef]

91. Yu, X.; He, W.; Li, H.; Yan, Y.; Lin, C. Larval settlement and metamorphosis of the pearl oyster Pinctada fucata in response to biofilms. Aquaculture 2010, 306, 334-337. [CrossRef]

92. Yang, J.L.; Li, X.; Liang, X.; Bao, W.Y.; Shen, H.D.; Li, J.L. Effects on natural biofilms on settlement of plantigrades of the mussel Mytilus coruscus. Aquaculture 2014, 424, 228-233. [CrossRef]

93. Radjasa, O.; Vaske, Y.; Navarro, G.; Vervoort, H.; Tenney, K.; Linington, R.; Crews, P. Highlights of marine invertebrate-derived biosynthetic products: Their biomedical potential and possible production by microbial associations. Bioorg. Med. Chem. 2011, 19, 6658-6674. [CrossRef] [PubMed]

94. Mendola, D. Aquaculture of three phyla of marine invertebrates to yield bioactive metabolites: Process developments and economics. Biomol. Eng. 2003, 20, 441-458. [CrossRef]

95. Pal-Singh, R.; Shukla, M.K.; Mishra, A.; Reddy, C.R.; Jha, B. Bacterial extracellular polymeric substances and their effect on settlement of zoospore of Ulva fasciata. Colloids Surf. B Biointerfaces 2013, 103, 223-230. [CrossRef] [PubMed]

96. Saleh, N.; Shalaby, S.M.; Sakr, E.M.; Abd-Elmonem, A.I.; Michael, F. Effect of dietary inclusion of Ulva fasciata on red hybrid tilapia growth and carcass composition. J. Appl. Aquac. 2014, 26, 197-207. [CrossRef]

97. Patil, J.; Anil, A.C. Influence of diatom exopolymers and biofilms on metamorphosis in the barnacle Balanus amphitrite. Mar. Ecol. Prog. Ser. 2005, 301, 231-245. [CrossRef]

98. Chen, Z.F.; Zhang, H.; Wang, H.; Matsumura, K.; Wong, Y.H. Quantitative proteomics study of larval settlement in the barnacle Balanus amphitrite. PLoS ONE 2014, 9, e88744. [CrossRef] [PubMed]

99. Whalan, S.; Webster, N.S. Sponge larval settlement cues: The role of microbial biofilms in a warming ocean. Sci. Rep. 2014, 4. [CrossRef] 
100. Louden, D.; Whalan, S.; Evans-Illidge, E.; Wolff, C.; de Nys, R. An assessment of the aquaculture potential of the tropical sponges Rhopaloeides odorabile and Coscinoderma sp. Aquaculture 2007, 270, 57-67. [CrossRef]

101. Webster, N.; Uthicke, S.; Botté, E.; Flores, F.; Negri, A. Ocean acidification reduces induction of coral settlement by crustose coralline algae. Glob. Chang. Biol. 2013, 19, 303-315. [CrossRef] [PubMed]

102. Caldeira, K.; Wickett, M.E. Oceanography: Anthropogenic carbon and ocean pH. Nature 2003, 425. [CrossRef] [PubMed]

103. Ross, P.; Parker, L.; O'Connor, W.; Bailey, E. The impact of ocean acidification on reproduction, early development and settlement of marine organisms. Water 2011, 3, 1005-1030. [CrossRef]

104. Meron, D.; Atias, E.; Lasur Kruh, L.; Elifantz, H.; Minz, D.; Fine, M.; Banin, E. The impact of reduced pH on the microbial community of the coral Acropora eurystoma. ISME J. 2011, 5, 5-60. [CrossRef] [PubMed]

105. Das, S.; Mangwani, N. Ocean acidification and marine microorganisms: Responses and consequences. Oceanologia 2015, 57, 349-361. [CrossRef]

106. Qian, P.Y.; Lau, S.; Dahms, H.U.; Dobretsov, S.; Harder, T. Marine biofilms as mediators of colonization by marine microorganisms: Implications for antifouling and aquaculture. Mar. Biotechnol. 2007, 9, 399-410. [CrossRef] [PubMed]

107. Totti, C.; Cucchiari, E.; De Stefano, M.; Pennesi, C.; Romagnoli, T.; Bavestrello, G. Seasonal variations of epilithic diatoms on different hard substrates, in the northen Adriatic Sea. J. Mar. Biol. Assoc. UK 2007, 87, 649-658. [CrossRef]

108. Braissant, O.; Decho, A.; Dupraz, C.; Glunk, C.; Przekop, K.; Visscher, P. Exopolymeric substances of sulfate-reducing bacteria: Interactions with calcium at alkaline $\mathrm{pH}$ and implication for formation of carbonate minerals. Geobiology 2007, 5, 401-411. [CrossRef]

109. Liu, J.; Weinbauer, M.; Maier, C.; Daii, M.; Gatusso, J. Effect of ocean acidification on microbial diversity, and on microbe-driven biogeochemistry and ecosystem functioning. Aquat. Microb. Ecol. 2010, 61, 291-305. [CrossRef]

110. Witt, V.; Wild, C.; Anthony, K.; Díaz-Pulido, G.; Uthicke, S. Effects of ocean acidification on microbial community composition of, and oxygen fluxes through, biofilms from the Great Barrier Reef. Environ. Microbiol. 2011, 13, 2976-2989. [CrossRef] [PubMed]

111. Primavera, J.H. Overcoming the impacts of aquaculture on the coastal zone. Ocean Coast. Manag. 2006, 49, 531-545. [CrossRef]

112. McCausland, W.D.; Mente, E.; Pierce, G.J.; Theodossiou, I. A simulation model of sustainability of coastal communities: Aquaculture, fishing, environment and labour markets. Ecol. Model. 2006, 193, 271-294. [CrossRef]

113. Rabalais, N. Eutrophication of estuarine and coastal ecosystems. In Environmental Microbiology, 2nd ed.; Mitchell, R., Gu, J.D., Eds.; Wiley-Blackwell: New York, NY, USA, 2010; pp. 115-135.

114. Dafforn, K.A.; Glasby, T.M.; Airoldi, L.; Rivero, N.K.; Mayer-Pinto, M.; Johnston, E.L. Marine urbanization: An ecological framework for designing multifunctional artificial structures. Front. Ecol. Environ. 2015, 13, 82-90. [CrossRef]

115. Mendiguchía, C.; Moreno, C.; Mánuel-Vez, M.; García-Vargas, M. Preliminary investigation on the enrichment of heavy metals in marine sediments originated from intensive aquaculture effluents. Aquaculture 2006, 254, 317-325. [CrossRef]

116. Shahidul-Islam, M.D.; Tanaka, M. Impacts of pollution on coastal and marine ecosystems including coastal and marine fisheries and approach for management: A review and synthesis. Mar. Pollut. Bull. 2004, 48, 624-649. [CrossRef] [PubMed]

117. Amin, M.T.; Alazba, A.A.; Manzoor, U. A review of removal of pollutants from water/wastewater using different types of nanomaterials. Adv. Mater. Sci. Eng. 2014. [CrossRef]

118. Lekang, O.I. Aquaculture Engineering, 2nd ed.; Wiley-Blackwell: Oxford, UK, 2013; Volume 6, pp. 50-64.

119. Manahan, S.E. Environmental Chemistry, 9th ed.; CRC Press: Boca Raton, FL, USA, 2010; Volume 5, pp. 103-124.

120. Koohestanian, A.; Hosseini, M.; Abbasian, Z. The separation method for removing of colloidal particles from raw water. Am. Eurasian J. Agric. Environ. Sci. 2008, 4, 266-273.

121. Castine, S.; McKinnon, A.D.; Paul, N.; Trott, L.; de Nys, R. Wastewater treatment for land-based aquaculture: Improvements and value-adding alternatives in model systems from Australia. Aquac. Environ. Interact. 2013, 4, 285-300. [CrossRef] 
122. Turcios, A.E.; Papenbrock, J. Sustainable treatment of aquaculture effluents-what can we learn from the past for the future? Sustainability 2014, 6, 836-856. [CrossRef]

123. Mirzoyan, N.; Tal, Y.; Gross, A. Anaerobic digestion of sludge from intensive recirculating aquaculture systems: Review. Aquaculture 2010, 306, 1-6. [CrossRef]

124. Li, X.Y.; Yang, S.F. Influence of loosely bound extracellular polymeric substances (EPS) on the flocculation, sedimentation and dewaterability of activated sludge. Water Res. 2007, 41, 1022-1030. [CrossRef] [PubMed]

125. Neyens, E.; Baeyens, J.; Dewil, R.; de Heyder, B. Advanced sludge treatment affects extracellular polymeric substantes to improve activated sludge dewateing. J. Hazard. Mater. 2004, 106, 83-92. [CrossRef] [PubMed]

126. Lee, C.; Robinson, J. A review on application of flocculants in wastewater treatment. Process Saf. Environ. Prot. 2014, 92, 489-508. [CrossRef]

127. Sharma, B.R.; Dhuldhoya, N.C.; Merchant, U.C. Flocculants-an ecofriendly approach. J. Polym. Environ. 2006, 14, 195-202. [CrossRef]

128. Bolto, B.; Gregory, J. Organic polyelectrolytes in water. Water Res. 2007, 42, 2301-2324. [CrossRef] [PubMed]

129. Özacar, M.; Şengil, I.A. Evaluation of tannin biopolymer as a coagulant aid for coagulation of colloidal particles. Colloids Surf. A Physicochem. Eng. Asp. 2003, 229, 85-96. [CrossRef]

130. Liu, Y.; Fang, H. Influences of extracellular polymeric substances (EPS) on flocculation, settling, and dewatering of activated sludge. Crit. Rev. Environ. Sci. Technol. 2003, 33, 237-273. [CrossRef]

131. Han, X.; Gu, J.D. Sorption and transformation of toxic metals by microorganisms. In Environmental Microbiology, 2nd ed.; Mitchell, R., Gu, J.D., Eds.; Wiley-Blackwell: New York, NY, USA, 2010; pp. 153-176.

132. Bhaskar, P.V.; Bhosle, N. Bacterial extracellular polymeric substance (EPS): A carrier of heavy metals in the marine food-chain. Environ. Int. 2006, 32, 191-198. [CrossRef] [PubMed]

133. Shapiro, K.; Krusor, C.; Mazzillo, F.; Conrad, P.; Largier, J.; Mazet, J.; Silver, M. Aquatic polymers can drive pathogen transmission in coastal ecosystems. Proc. R. Soc. B 2014, 281. [CrossRef] [PubMed]

134. Ikem, A.; Egiebor, N.O. Assessment of trace elements in canned fishes (mackerel, tuna, salmon, sardines and herrings) marketed in Georgia and Alabama (United States of America). J. Food Compos. Anal. 2005, 18, 771-787. [CrossRef]

135. Wang, Z.; Hessler, C.; Xue, Z.; Seo, Y. The role of extracellular polymeric substances on the sorption of natural organic matter. Water Res. 2012, 46, 1052-1060. [CrossRef] [PubMed]

136. Sanz-Lázaro, C.; Navarrete-Mier, F.; Marín, A. Biofilm responses to marine fish farm wastes. Environ. Pollut. 2011, 159, 825-832. [CrossRef] [PubMed]

137. Amara, R.; Filipuci, I.; Vincent, D.; Goulard, F.; Breton, E. Do transparent exopolymeric particles (TEP) derived from Phaeocytis globose bloom impact the physiological performances of European sea bass juveniles. Aquaculture 2013, 414-415, 149-154. [CrossRef]

138. Treasurer, J.; Hannah, F.; Cox, D. Impact of a phytoplankton bloom on mortalities and feeding response of farmed Atlantic salmon, Salmo salar, in west Scotland. Aquaculture 2003, 218, 103-113. [CrossRef]

139. Shumway, S. A review of the effects of algal blooms on shellfish and aquaculture. J. World Aquac. Soc. 1990, 21, 65-104. [CrossRef]

140. Rodríguez, G.; Villasante, S.; García-Negro, M. Are red tides affecting economically the commercialization of the Galician (NW Spain) mussel farming? Mar. Policy 2011, 35, 252-257. [CrossRef]

141. Lu, D.; Huang, W. Phaeocytis bloom in southeast China coastal water 1997. Harmful Algal News 1999, 19, 9.

142. Sellner, K.; Doucette, G.; Kirkpatrick, G. Harmful algal blooms: Causes, impacts and detection. J. Ind. Microb. Biotechnol. 2003, 30, 383-406. [CrossRef] [PubMed]

143. Kumar-Mandal, S.; Pal-Singh, R.; Patel, V. Isolation and characterization of exopolysaccharide secreted by a toxic dinoflagellate, Amphidinium carterae Hulburt 1957 and its probable role in harmful algal blooms (HABs). Microb. Ecol. 2011, 62, 518-527. [CrossRef] [PubMed]

144. Yamasaki, Y.; Shikata, T.; Nukata, A.; Ichiki, S.; Nagasoe, S.; Matsubara, T.; Shimasaki, Y.; Nakao, M.; Yamaguchi, K.; Oshima, Y.; et al. Extracellullar polysaccharide-protein complexes of a harmful alga mediate the allelopathic control it exerts within the phytoplankton community. ISME J. 2009, 3, 808-817. [CrossRef] [PubMed]

145. Passow, U.; Alldredge, A.L. Do transparent exopolymers particles (TEP) inhibit grazing by the euphausiid Euphausia superba? J. Plankton Res. 1999, 21, 2203-2217. [CrossRef]

146. Kumar, A.S.; Mody, K.; Bhavanath, J. Bacterial exopolysaccharides-A perception. J. Basic Microbiol. 2007, 47, 103-117. [CrossRef] [PubMed] 
147. Freitas, F.; Alves, V.; Reis, M.A. Advances in bacterial exopolysaccharides: From production to biotechnological applications. Trends Biotechnol. 2011, 29, 388-398. [CrossRef] [PubMed]

148. More, T.T.; Yadav, J.S.; Yan, S.; Tyagi, R.D.; Surampalli, R. Extracellular polymeric substances of bacteria and their potential environmental applications. J. Environ. Manag. 2014, 144, 1-25. [CrossRef] [PubMed]

149. Nácher-Vázquez, M.; Ballesteros, N.; Canales, A.; Saint-Jean, S.; Pérez-Prieto, S.; Prieto, A.; Aznar, R.; López, P. Dextrans produced by lactic acid bacteria exhibit antiviral and immunomodulatory activity against salmonid viruses. Carbohydr. Polym. 2015, 124, 292-301. [CrossRef] [PubMed]

150. Wan, C.; Zhao, X.Q.; Guo, S.L.; Alam, A.; Bai, F.W. Bioflocculant production from Solibacillus silvestris W01 and its application in cost-effective harvest of marine microalga Nannochloropsis oceanica by flocculation. Bioresour. Technol. 2013, 135, 207-212. [CrossRef] [PubMed]

151. Farmaki, E.; Thomaidis, N.; Pasias, I.; Baulard, C.; Papaharisis, L.; Efstathiou, C. Environmental impact of intensive aquaculture: Investigation on the accumulation of metals and nutrients in marine sediments of Greece. Sci. Total Environ. 2014, 485, 554-562. [CrossRef] [PubMed]

152. Ferry, J.L.; Craig, P.; Hexel, C.; Sisco, P.; Frey, R.; Pennington, P.; Fulton, M.; Scott, I.G.; Decho, A.W.; Kashiwada, S.; et al. Transfer of gold nanoparticles from the water column to the estuarine food web. Nat. Nanotechnol. 2009, 4, 441-444. [CrossRef] [PubMed]

153. Andalecio, M.N.; Napata, R.P.; Garibay, S.S. Aquaculture response and recovery from the effects of M/T Solar 1 oil spill. J. Aquac. Mar. Biol. 2014, 1. [CrossRef]

154. Ortega-Morales, B.O.; Santiago-García, J.L.; Chan-Bacab, M.J.; Moppert, X.; Miranda-Tello, E.; Fardeau, M.L.; Carrero, J.C.; Bartolo-Pérez, P.; Valadéz-González, A.; Guezennec, J. Characterization of extracelular polymers synthesized by tropical intertidal biofilm bacteria. J. Appl. Microbiol. 2006, 102, 254-264. [CrossRef] [PubMed]

155. Camacho-Chab, J.C.; Guézennec, J.; Chan-Bacab, M.J.; Ríos-Leal, E.; Sinquin, C.; Muñiz-Salazar, R.; De la Rosa-García, S.; Reyes-Estebanez, M.; Ortega-Morales, B.O. Emulsifying activity and stability of a non-toxic bioemulsifier syntheszed by Microbacterium sp. MC3B-10. Int. J. Mol. Sci. 2013, 14, 18959-18972. [CrossRef] [PubMed]

156. Gutierrez, T.; Mully, B.; Black, K.; Green, D.H. Glycoprotein emulsifiers from two marine Halomonas species: Chemical and physical characterization. J. Appl. Microbiol. 2007, 103, 1716-1727. [CrossRef] [PubMed]

157. Gutierrez, T.; Biller, D.V.; Shimield, T.; Green, D.H. Metal binding properties of the EPS produced by Halomonas sp. TG39 and its potential in enhancing trace element bioavailability to eukaryotic phytoplankton. Biometals 2012, 25, 1185-1194. [CrossRef] [PubMed]

158. García, N.; López-Elías, J.; Miranda, A.; Martínez-Porchas, M.; Huerta, N.; García, A. Effect of a salinity on growth and chemical composition of the diatom Thalassiosira weissflogii at three culture phases. Lat. Am. J. Aquat. Res. 2012, 40, 435-440. [CrossRef]

159. Hassler, C.; Alasonati, E.; Mancuso-Nichols, C.; Slaveykova, V. Exopolysaccharides produced by bacteria isolated from the pelagic Southern Ocean-Role in Fe binding, chemical reactivity, and bioavailability. Mar. Chem. 2011, 123, 88-98. [CrossRef]

160. Ndikubwimana, T.; Chang, J.; Xiao, Z.; Shao, W.; Zeng, X.; Ng, I.-S.; Lu, Y. Flotation: A promising microalgae harvesting and dewatering technology for biofuels production. Biotechnol. J. 2016, 11, 315-326. [CrossRef] [PubMed]

161. Salim, S.; Bosma, R.; Vermuë, M.; Wijffels, R. Harvesting of microalgae by bio-flocculation. J. Appl. Phycol. 2011, 23, 849-855. [CrossRef] [PubMed]

162. Lei, W.; Chen, Y.; Shao, Z.; Chen, Z.; Li, Y.; Zhu, H.; Zhang, J.; Zheng, W.; Zheng, T. Effective harvesting of the microalgae Chlorella vulgaris via flocculation-flotation with bioflocculant. Bioresour. Technol. 2015, 198, 922-925. [CrossRef] [PubMed]

163. Van Den Hende, S.; Vervaeren, H.; Desmet, S.; Boon, N. Bioflocculation of microalgae and bacteria combined with flue gas to improve sewage treatment. New Biotechnol. Recent Adv. Environ. Biotechnol. 2011, 29, $23-31$. [CrossRef]

164. Van Den Hende, S.; Beelen, V.; Bore, G.; Boon, N.; Vervaeren, H. Up-scaling aquaculure wastewater treatment by microalgal bacterial flocs: From lab reactors to an outdoor raceway pond. Bioresour. Technol. 2014, 159, 342-354. [CrossRef] [PubMed] 
165. Kasan, N.; Said, S.; Ghazali, N.; Che, N.; Ibrahim, Z.; Amin, N. Application of biofloc in aquaculture: An evaluation of flocculating activity of selected bacteria from biofloc. In Beneficial Microorganisms in Agriculture, Aquaculture and Other Areas; Liong, M.T., Ed.; Springer International Publishing: Cham, Switzerland, 2015; pp. 165-182.

166. Rairakhwada, D.; Pal, A.K.; Bhathena, Z.P.; Sahu, N.P.; Jha, A.; Mukherjee, S.C. Dietary microbial levan enhances cellular non-specific immunity and survival of common carp (Cyprinus carpio) juveniles. Fish Shellfish Immunol. 2007, 22, 477-486. [CrossRef] [PubMed]

167. Simon-Colin, C.; Gueguen, Y.; Bachere, E.; Kouzayha, A.; Saulnier, D.; Gayet, N.; Guezennec, J. Use of natural antimicrobial peptides and bacterial biopolymers for cultured pearl production. Mar. Drugs 2015, 13, 3732-3744. [CrossRef] [PubMed]

168. Gupta, S.K.; Das, P.; Singh, S.; Akhtar, M.; Meena, D.; Mandal, S. Microbial levan, an ideal prebiotic and immunonutrient in aquaculture. World Aquac. 2011, 42, 61. [CrossRef]

169. Gupta, S.K.; Pal, A.; Sahu, N.; Saharan, N.; Mandal, S.; Prakash, C.; Akhtar, M.; Prusty, A. Dietary microbial levan ameliorates stress and augments immunity in Cyprinus carpio fry (Linnaeus 1758) exposed to sublethal toxicity of fipronil. Aquac. Res. 2014, 45, 893-906. [CrossRef]

170. Gupta, S.K.; Pal, A.K.; Sahu, N.P.; Dalvi, R.; Kumar, V.; Mukherjee, S.C. Microbial levan in the diet of Labeo rohita Hamilton juveniles: Effect on non-specific immunity and histopathological changes after challenge with Aeromonas hydrophila. J. Fish Dis. 2008, 31, 649-657. [CrossRef] [PubMed]

171. Jung, H.K.; Hong, J.H.; Park, S.C.; Park, B.K.; Nam, D.H.; Kim, S.D. Production and physicochemical characterization of $\beta$-glucan produced by Paenibacillus polymyxa JB115. Biotechnol. Bioprocess Eng. 2007, 12, 713-719. [CrossRef]

172. Kiran, G.; Lipton, A.; Priyadharshini, S.; Anitha, K.; Cruz-Suárez, L.; Valan, M.; Choi, K.; Selvin, J. Antiadhesive activity of poly-hydroxy butyrate biopolymer from a marine Brevibacterium casei MS104 against shrimp pathogenic vibrios. Microb. Cell Fact. 2014, 13, 114-126. [CrossRef] [PubMed]

(C) 2016 by the authors; licensee MDPI, Basel, Switzerland. This article is an open access article distributed under the terms and conditions of the Creative Commons Attribution (CC-BY) license (http://creativecommons.org/licenses/by/4.0/). 